УДК 373.5.091.32:811.111 (07)

DOI: $\underline{10.35619 / \text { iiu.v2i11.273 }}$

\author{
Olha Bezkorovaina \\ Doctor of Pedagogic Sciences, \\ Full Professor, Head at the Department \\ of Foreign Language Teaching Methodology \\ Rivne State University for the Humanities, \\ Rivne, Ukraine \\ ORCID: 0000-0001-7144-9946, \\ e-mail: olg2686@gmail.com
}

Dyshchakovska Olha

Student at the Foreign Language Faculty,

Rivne State University for the Humanities,

Rivne, Ukraine

ORCID: 0000-0002-7047-7440,

e-mail:dyshchakovska@ukr.net

\title{
INTERACTIVE TEACHING METHODS IN FOREIGN LANGUAGE LEARNING: THEORETICAL ANALYSIS OF THE PROBLEM
}

\begin{abstract}
The article is devoted to the problem of organization of interactive lessons, emphasizing their important role in improving the quality of education, description the most popular interactive teaching methods (role play, presentation, conversations, brainstorming, projects, podcasting, video files, blogging, round table, discussion, situational analysis) at the English language lessons with students .

It is proved that interactive learning is aimed at teaching students to be actively involved in their learning process. There are different ways to create such participation. This is mostly through teacher-student interaction, student-student interaction, the use of audio, video, video hands-on demonstrations, and exercises.Students are encouraged to be active members of the class, thinking on their own, using their brains, resulting in long-term memory retention. Interactive teaching methods are the actual way of teacher's work in classroom, group or any educational institution. Interactive teaching methods, in contrast to the traditional ones, are based on the active interaction of participants in the educational process, and special attention is paid upon students' interaction with each other. This approach allows teachers: 1) to create a classroom atmosphere that helps to encourage students to ask questions and seek answers, take (as a basis) the following types of training that would facilitate the development of critical thinking and independent acquisition of knowledge, encourage reflection; 2) to apply existing methods to become a thoughtful professional, that means to learn how to observe carefully, identify problems and create new strategies to solve them; 3) to be a model for other students, transfer knowledge to them.

It was concluded, that the use of interactive methods in teaching a foreign language to future technicians helps to organize an active interaction of all participants of the communication process which results in the exchange of professional information in a foreign language and the acquisition of professional qualities and practical skills of communication.
\end{abstract}

Key words: interactive teaching methods, speech skills, interaction, speech activity, information and communication technologies.

(C) Bezkorovaina O.,

Dyshchakovska O, 2020 
Problem statement. Organization of interactive lessons plays an important role in improving the quality of education. It is important to reveal the essence and peculiarities of using interactive methods in foreign and Ukrainian literature; to find a complex of different interactive technologies in teaching English

Research publications. Introduction of innovative technologies into the educational process, an important place among which belongs to the interactive ones, is the main direction of improvement in the study of foreign language. The essence of interactive learning is highlighted in the works of N. Balytska, H. Voloshyna, O. Hlotov, N. Pobirchenko, A. Pometun, L. Pyrozhenko and others. The problem of using interactive methods was reflected in the scientific works of such scholars as N. Azarov, I. Bekh, N. Matveieva, L. Nikolaieva, O. Panchenko, N. Stetsur and others.

Thus, the research aim and objective is: to consider the general characteristics of interactive lessons and methods, the purpose of their formation; to describe the means of of communication skills at the highest level and control the level of their formation, to substantiate the importance of using interactive methods of teaching English.

Presenting the main research material. The notion "interactive" ("inter" means mutual, "act"-act) means "to interact". "Interactive learning" can be defined as the interaction of a teacher and a student in the process of communication and learning in order to solve linguistic and communicative tasks. Interactive activities include the organization and development of dialogical speech, aimed at interaction, mutual understanding, solving problems, which are important for each participant of the educational process.

The structure of English classes with the use of interactive technologies takes place in four stages: 1) preparation (this stage foresees organizational moments, such as handouts, necessary technical means); 2) introduction (at this stage it is important to explain rules, goals, technically formed tasks, division into groups, distribution of roles and timing for the game); 3) conducting (discussion of the situations given by the teacher, independent or group search of solutions, formation of answers are compulsory); 4) reflection and results (the elements of this given stage are discussion of the results of the game, evaluation, feedback) (Gin, 2000, p. 7-11).

Interactive interaction is characterized by a high indicator of the intensity of communication of participants, their direct communication, change of used methods and forms of communication, which helps to diversify the perception of information, thereby improving its learning (Pometun, Pyrozhenko, 2004, p. 35-37).

It should be noted that the choice of the form of conducting an interactive lesson requires an individual approach of the teacher, taking into account the level of his/her intellectual development, the studied theme and the objectives. Interactive learning technologies can be used to conduct classes inside or outside the classroom in the form of extracurricular activities. The method of conducting a lesson is active, that is, no student is left without attention and, in a favorable atmosphere, even passive students tend to be active participants.

Interactive teaching methods include: presentation, heuristic conversations, role plays, discussions, "brainstorming", competitions with practical tasks and their further discussion, design of technical plans, projects, carrying out of creative activities, the use of multimedia computer programs and the involvement of English-speaking professionals.

The project can be defined as a set of tasks that foresee an organized, long-term, independent students' study of foreign language, which is carried out at the classes and during extra hours, the purpose of which is to create a definite final product in the form of booklet, newspaper, video etc., and oral presentation on the chosen problem with the use of varied visibility. 
The project methodology is effective for mastering one of the components of communicative competence - the socio-cultural component (when foreign language teaching is on the basis of the involvement of material of ethnographic character). The project methodology makes it possible to learn cultural information, draw parallels between cultures of different nations, find common features and differences, form a respectful and tolerant attitude to socio-cultural differences.

It is necessary to organize work in such a way that it will allow students to demonstrate creative and intellectual abilities, achievement, develop creative thinking and learn to communicate with other people.

It should be also noted that interactive online learning is becoming popular. The benefits of using interactive online learning systems are accessibility, flexibility, absence of stress, quality of learning, personalized counseling, time and place for learning, time savings and improved computer skills (Prosianyk, 2013, p.88).

Among the methods of interactive online education, the following ones were distinguished: 1) podcasting - a way of publishing media streams (usually audio or video programs) on the World Wide Web (usually in MP3 format), which are announced in a special way, which allows to download new releases to the device automatically. For convenient reproduction of podcasts, software is created that regularly asks the website for new records to be uploaded to the user's computer. 2) video files help students learn the lesson better than they just read or hear it. 3) blogging.

The blog is a kind of site that is occasionally filled with text and multimedia information, and the latest blog records are displayed in reverse chronological order. Students have the opportunity to express their thoughts about the posted articles, and the teacher - to make some changes in the contents if there is a need, thanks to a quick feedback. The learning management system is specifically designed for online learning. This system allows the teacher to create, post and monitor the implementation of the course tasks, send homework and register students for the course. Students can perform tasks online, or by uploading, make and send them to the teacher's email for verification. One of the most common learning management systems is Moodle.

"Round Table" - a method of conducting classes with students who, as a rule, have the experience of practical work on the subject under discussion. At the "round table", listeners can and should try to ask questions on the topic of discussion rationally, argue approaches to their solution seriously, and report on successful and bad experience. The "Round Table" is a kind of meeting on the exchange of experience and discussion of practical experience, achievements and mistakes. In this way, the students master the contents of the topic, its problems.

A role-playing game simulates future professional activities, contributes to the development of the students' skills and competence as foreseen by the qualification characteristics. The game model of learning allows those who learn not only to feel themselves in a certain communicative role, but also to reveal their emotions, intellectual abilities, creative imagination (Azarova, 2011, pp. 7-13).

It is distinguish such role playing as: simulation or imitation, performance (drama) and gamecompetition (game). Often they are identified, but in general they mean different concepts. The difference between role playing and simulation is the probability of roles played by the listeners. So, simulation is a situation in which those who are learning perform roles that are natural to them in their real life. In the role-playing game, however, they can "try on themselves" roles that they do not embody in their lives.

Role, imitation games and simulations or situational modeling are especially useful for future professional activities. The use of imitations and simulations allows not only to perform actions that repeat the phenomena of the surrounding reality, but also to recreate the real situations of 
professional life in specially created conditions. The topics for role-playing games, imitations in the teaching foreign language to students may be related to their future professional and scientific activities: "Job hunting: interview with the employer", "Scientific conference, symposium".

The other active methods, which allow plan English lesson more effective and interesting for listeners is the method of brainstorming, which helps to solve urgent tasks in a short time. The essence of the method lies in the fact that it is necessary to express ideas, as much as possible, in a short period of time, discuss them and classify them. This method is used to solve complex problemsand can be used in various types of activities: in work with small and large training groups, individual work.

The discussion is an active method of conducting classes, designed to mobilize practical and theoretical knowledge, the views of listeners on the problem. The discussion is relevant when considering controversial issues (but in the learning process, situation of controversy of interpretations may not arise). For these reasons, it is not correct to plan lessons as discussion in advance. When discussion is a curriculum outcome, teachers have purposes for teaching discussion, and they explicitly teach students how to be discussants. Teachers report that they want their students to develop discussion skills for many of the same reasons that they teach with discussion. If students will engage in discussions outside of the classroom, then the possibility of students building knowledge and exploring multiple perspectives about issues also extends outside of the classroom. An additional purpose for teaching students how to engage in discussion related to citizenship education and preparing students to discuss issues and policies. Teachers think of discussion as a skill that requires practice sessions. At times they plan discussions so students may practice engaging in verbal interactions with one another. They believe that students become better discussants when they watch the teacher model appropriate behavior during a discussion, then receive opportunities to practice engaging in discussions.

Situational analysis means students, having reviewed the description of the problem, analyze the situation independently, diagnose the problem and give their ideas and solutions during discussions with other listeners. Depending on the nature of the material's presentation, situationsillustrations, situation-assessment and situation-exercises are used.

Analysis of specific situations is the most suitable method of situational analysis in educational conditions - a traditional analysis of specific situations, including a deep and detailed study of real or imitation situation. The usage of the method of analysis of specific situations allows to solve the following educational goals: the development of analytical thinking, the application of analysis in dynamics; mastering the practical skills of working with information (selection, structuring and ranking on the importance of problems); making decisions; development of modern technologies; expansion of communicative competence; formation of the ability to choose the best options for effective interaction with other people; stimulating innovation; increasing motivation to study problem theory.

Conclusions and further research prospects. So, after analyzing the given problem, we can conclude that interactive teaching methods contribute to optimizing the learning process for the study of a professional foreign language. They are intended to put mechanisms for motivation in place and increase the efficiency of teaching foreign language communication. The advantages of using interactive methods in the process of students' learning include the maximum approximation to the real conditions of professional activity, the broad autonomy of students, decision making in conditions of creative competition and the development of skills for spontaneous speech, promoting the development of organizational skills of students, overcoming the barrier between the study of language and its practical application. 
It comes to the conclusion that the use of interactive methods in teaching a foreign language to future specaalists help to organize an active interaction of all participants of the communication process which results in the exchange of professional information in a foreign language and the acquisition of professional qualities and practical skills of communication.

The theoretical study of the problem raised in the article outlines the prospects for further research, in particular the definition of criteria for the selection of interactive teaching methods, which will increase the efficiency of English classes. Therefore, the development of the topic of this problem should be further studied in our subsequent publications.

\section{СПИСОК ВИКОРИСТАНИХ ДЖЕРЕЛ}

Gin, A. (2000). No bloody attack: Brainstorming training technology: [Interesting and simple form of training]. 8, p. 7-11.

Пометун, О. (2014) Сучасний урок. Інтерактивні технології навчання. Київ:А.С.К

Просяник, О. (2013). Інтерактивне онлайн-навчання іноземній мові. Сучасні засоби навчання іноземних мов у вищих навчальних закладах. Національний університет «Юридична академія України імені Ярослава Мудрого. Харків: НУ «ЮАУ ім. Ярослава Мудрого»

Азарова, Н. (2011). Інтерактивні технології навчання майбутніх правників .Психологопедагогічні проблеми сільської школи : збірник наукових праџь Уманського держсавного педагогічного університету імені Павла Тичини. Умань : ПП Жовтий О. О. С. 7-13.

Безкоровайна, О. (2016). Інноваційна діяльність викладача іноземної мови: проблеми теорії та практики. Оновлення змісту, форм та методів навчання і виховання в закладах освіти:науковий збірник : наукові записки РДГУ. Випуск14 (57). С. 50-60.

Дищаковська, О., та Безкоровайна, О. (2020). Організація нестандартного уроку іноземної мови як засобу активізації комунікативної діяльності старшокласників. Фундаментальні та прикладні наукові дослідження: актуальні питання, досягнення та інновації : матеріали I Міжнародної науково-практичної інтернет - збірник тез. С. 121124.

Дищаковська, О. (2020). Використання психолого-педагогічного аспекту під час проведення нестандартного уроку з іноземної мови. Актуальні питання науки: матеріали I Міжнар. наук.-практ. інтернет-конф.: зб. тез. Бердянськ: БДПУ. С. 179-182.

\section{REFERENCES}

Gin, A. (2000). No bloody attack: Brainstorming training technology: [Interesting and simple form of training].8, pp. 7-11.

Pometun, O. \& Pyrozhenko, L. (2004). Suchasnyi urok. Interaktyvni tekhnolohii navchannia [Modern Lesson. Interactive Learning Technologies]. Kyiv: A.S.K.

Prosyanyk, O. (2013). Interaktyvne onlain-navchannia inozemnii movi. Suchasni zasoby navchannia inozemnykh mov $u$ vyshchykh navchalnykh zakladakh. [Interactive Online Foreign Language Teaching. Modern Means of Teaching Foreign Languages in Higher Educational Institutions] Natsionalnyi universytet "Yurydychna akademiia Ukrainy imeni Yaroslava MudrohoKharkiv: NU "IuAU im. Yaroslava Mudroho"

Azarova, N. (2011). Interaktyvni tekhnolohii navchannia maibutnikh pravnykiv .Psykholohopedahohichni problemy silskoi shkoly : zbirnyk naukovykh prats Umanskoho derzhavnoho pedahohichnoho universytetu imeni Pavla Tychyny. [Interactive Technologies of Future Lawyers' Training] In: Psychologicalpedagogical problems of the village school: a collection of scientific 
works of the Uman State Pedagogical University named after Pavlo Tychyna]/ Uman: PP Zhovtyi O. O., 39. S. 7-13.

Bezkorovaina, O.(2016). Innovatsiina diialnist vykladacha inozemnoi movy: problemy, teorii ta praktyky [Innovative Activity of a Foreign Language Teacher: Problems of Theory and Practice] .Onovlennia zmistu, form ta metodiv navchannia i vykhovannia v zakladakh osvity: naukovyi zbirnyk : naukovi zapysky RDHU Vypusk 14(57),. S. 50-60.

Dyshchakovska, O. \& Bezkorovaina, O. (2020). Orhanizatsiia nestandartnoho uroku inozemnoi movy yak zasobu aktyvizatsii komunikatyvnoi diialnosti starshoklasnykiv [Organization of Interactive English Lesson as Means of Communication of Senior Students]. Fundamentalni ta prykladni naukovi doslidzhennia: aktualni pytannia, dosiahnennia ta innovatsii. $V$ : materialy I Mizhnarodnoi naukovo-praktychnoi internet-zbirnyk tez. s. 121-124.

Dyshchakovska, O. (2020) Vykorystannia psykholoho-pedahohichnoho aspektu pid chas provedennia nestandartnoho uroku z inozemnoi movy. [The Use of Psychological and Pedagogical Aspects during a Non-standard Lesson in a Foreign Language]. Aktualni pytannia nauky : materialy I Mizhnar. nauk.-prakt. internet-konf.: zb. tez. Berdiansk : BDPU, 2020. S. 179-182.

\title{
ІНТЕРАКТИВНІ МЕТОДИ НАВЧАННЯ У ВИВЧЕННІ ІНОЗЕМНОЇ МОВИ: ТЕОРЕТИЧНИЙ АНАЛІЗ ПРОБЛЕМИ
}

\author{
Безкоровайна Ольга \\ доктор педагогічних наук, професор, \\ завідувачка кафедри методики \\ викладання іноземних мов \\ факультету іноземної філології \\ Рівненського державного гуманітарного університету \\ м. Рівне, Україна \\ ORCID: 0000-0001-7144-9946, \\ e-mail: olg2686@gmail.com \\ Дищаковська Ольга \\ студентка факультету іноземної філології \\ Рівненського державного гуманітарного університету \\ м. Рівне, Україна \\ ORCID: 0000-0002-7047-7440 \\ e-mail: dyshchakovska@ukr.net
}

\footnotetext{
Анотація. Стаття розкриває роль і значення інтерактивних форм і методів навчання у процесі оволодіння іноземною мовою - рольова гра, презентація, бесіди, мозковий штурм, проєкти, відео файли, блоги, круглий стіл, дискусія, ситуаційний аналіз тощо. Доведено переваги інтерактивного навчання. Розкрито способи ефективної взаємодії в режимі «викладач - студент», «студент - студент», «студент - відеоролики», «студент - вправи» тощо, що сприяє розвитку активної мислительної діяльності, аналізу та синтезу, порівнянню та узагальненню.

Інтерактивні методи навчання $є$ ефективними при роботі з школярами чи студентами різних типів закладів освіти, оскільки вони, на відміну від традиційних, грунтуються на активній взаємодії всіх учасників освітньо-виховного процесу. Такий підхід дозволяє викладачеві: 1) створити атмосферу довіри та взаємодопомоги, яка допомагає студентам
} 
ставити запитання та шукати відповіді; при цьому мовленнєві тренінги виступають одним 3 еефкетивних способів діяльності, оскільки вони сприяють розвитку критичного мислення, уміння самостійно набувати знання; 2) застосовувати класичні методи навчання, оволодівати професійним мовленням, що ефективно впливає на виявлення існуючих проблем та створення нових стратегій для їх вирішення; 3) бути мовленнєвим зразком (моделлю) для інших. Учасники інтерактивного навчання вчаться ставити перед собою навчальні цілі, розвивати навчальну діяльність, виявляти проблеми в процесі навчання.

З»ясовано, що інтерактивне навчання важливе для особистісного розвитку та професійного зростання. Взаємодія допомагає долучатися до виконання різних видів робіт, що позитивно впливає на розвиток мовленнєвого вокабуляру кожного учасника освітнього процесу, на вибір студентом навчальних ресурсів, в т.ч. й інформаційно-комунікативних технологій.

Ключові слова: інтерактивні методи навчання, мовленнєві уміння й навички, взаємодія, мовленнєва діяльність, інформаційно-комунікативні технології.

Стаття надійшла до редакиії 10.05.2020 p 